\title{
Modifikasi Metode Waldvogel Berdasarkan Identifikasi Karakteristik Hujan Es yang Dikelompokkan Berdasarkan Jarak Cakupan Radar Cuaca Pada Radar Cuaca Jakarta Tahun 2010-2019
}

\author{
Marselinus Muaya ${ }^{1 *}$ Amalia Khoirunnisa ${ }^{2}$, Rizky Umul Nisa Fadillah ${ }^{3}$, Eko Wardoyo ${ }^{4}$, \\ Fitria Puspita Sari ${ }^{5}$
}

${ }^{1,2,3}$ Program Studi Meteorologi, Sekolah Tinggi Meteorologi Klimatologi dan Geofisika, Jalan

Perhubungan I No.5 Pondok Betung, Bintaro, Kec. Pd. Aren, Kota Tangerang Selatan, Banten 15221

${ }^{4,5}$ Dosen Program Studi Meteorologi, Sekolah Tinggi Meteorologi Klimatologi dan Geofisika, Jalan

Perhubungan I No.5 Pondok Betung, Bintaro, Kec. Pd. Aren, Kota Tangerang Selatan, Banten 15221

${ }^{*}$ E-mail: marcelmuaya21@gmail.com

\begin{abstract}
Hail detection using information from satellite and weather radar is the right choice due to spatial and temporal variability of the phenomenon of high hail. Some algorithms that use single polarization radar data have been developed for hail detection. One method that has been applied in Reflectivity-based Hail Warning or ZHAIL radar product is the Waldvogel method. This research aims to find new threshold criteria for the application of the Waldvogel method in the Jakarta weather radar observation area which is grouped into three regions based on the distance of weather radar observation. In this research, hail events from 2010 to 2019 have been analysed. Analysis of weather and weather radar data was carried out to determine the climatological characteristics of reflectivity values, reflectivit heights, and freezing levels as parameters to be used to determine the criteria for modification in the Waldvogel method. The reflectifity and reflectivity values are obtained from the processing of radar data, while the freezing level is generated from the processing of the Himawari satellite image in the infrared channel. Waldvogel's algorithm with the three modifications that have been produced, then tested using Critical Success Index, Possibility of Detection, and False Alram Ratio, calculations on the percentage value of Probability Of Hail. The results of the research is the reflectivity values, reflectivity altitude and the most accurate freezing level applied to each region that was differentiated according to the weather radar distance radius observation. Better accuracy of the application of Waldvogel method is expected to reduce therougheffects ofthehail phenomenon.
\end{abstract}

Keywords: Hail, Waldvogel methods, Freezing Level, weather radar

\begin{abstract}
Abstrak: Metode Waldvogel merupakan metode deteksi hujan es yang mengubah reflectivity dari pengamatan radar menjadi produk Reflectivity-based Hail Warning atau ZHAIL. Penggunaan metode Waldvogel masih perlu disesuaikan dengan kondisi wilayah tropis termasuk Indonesia. Penelitian ini bertujuan untuk menemukan kriteria ambang batas baru untuk penerapan metode Waldvogel di daerah pengamatan radar cuaca Jakarta sehingga diperoleh akurasi metode Waldvogel yang lebih baik. Kriteria ambang dikelompokkan menjadi tiga wilayah berdasarkan jarak cakupan radar cuaca (wilayah I $:<30 \mathrm{~km}$, wilayah II $: 30-100 \mathrm{~km}$ dan wilayah III $: 100-150 \mathrm{~km}$ ). Analisis data radar cuaca dilakukan untuk menentukan karakteristik klimatologis dari nilai reflectivity maksimum, ketinggian reflectivity maksimum, dan ketinggian freezing level sebagai parameter yang akan digunakan untuk menentukan kriteria modifikasi dalam metode Waldvogel. Verfikasi parameter diujikan dengan nilai Probability of Hail (POH), False Alarm Ratio (FAR), Possibility of Detection (POD), dan Critical Success Index (CSI). Hasil verifikasi menunjukan metode Waldvogel modiifikasi menghasilkan performa yang lebih baik dibandingkan metode Waldvogel awal untuk wilayah I dan II dengan kriteria metode Waldvogel modifikasi yang paling baik yaitu Waldvogel 3. Sedangkan untuk wilayah III, nilai kriteria yang lebih baik adalah Waldvogel tanpa modifikasi. Akurasi yang lebih baik dari penerapan metode Waldvogel diharapkan dapat mengurangi dampak buruk yang ditimbulkan dari fenomena hujan es.
\end{abstract}

Kata kunci: Hail, metode Waldvogel, Freezing Level, radar cuaca, ZHAIL 


\section{PENDAHULUAN}

Hujan es dihasilkan dari gerakan massa udara (updraft) kuat awan Cumulonimbus bersel tunggal (single cell) maupun ganda (multicell) yang terletak dekat permukaan bumi (Zakir, 2008). Partikel es (hailstone) terbentuk saat tetes hujan yang membeku tumbuh melalui proses koalisi dan koalisensi dari tetes awan kelewat jenuh yang menyebabkan penambahan massa partikel (Roger dan Yau, 2006). Sistem konvektif kuat disertai ketinggian freezing level yang rendah menyebabkan butiran es berukuran besar tidak memiliki waktu yang cukup untuk menjadi tetes hujan ketika jatuh mencapai permukaan tanah (Lutgens dan Tarbuck, 2013).

Metode deteksi hujan es menggunakan radar cuaca telah banyak diteliti diberbagai negara. Penelitian yang dilakukan oleh Holleman (2001) di Belanda berupa verifikasi yang dilakukan terhadap delapan metode deteksi hujan es berbeda, didapatkan metode Waldvogel memiliki performa yang paling baik dengan nilai Critical Succesess Index (CSI) sebesar 0.54. Dalam penelitian Skripniková dan Řezáčová (2014) di Republik Ceko dan Jerman, mengungkapkan bahwa metode Waldvogel dan Severe Hail Algorithm dari NextGeneration Radar (NEXRAD) adalah yang paling akurat dari tujuh metode deteksi hujan es yang diujikan.

Metode Waldvogel yang dikembangkan oleh Albert Waldvogel (1979) adalah metode deteksi kejadian hujan es dengan menggunakan dua parameter, yaitu ketinggian pada reflectivity $45 \mathrm{dBZ}(\mathrm{H} 45)$ dan ketinggian freezing level atau ketinggian pada suhu $0^{\circ} \mathrm{C}(\mathrm{H} 0)$. Ketika ketinggian pada reflectivity $45 \mathrm{dBz}$ meningkat hingga $1.4 \mathrm{~km}$ atau lebih diatas freezing level maka hujan es akan sangat mungkin terjadi dan probabilitas kejadian hujan es meningkat seiring dengan meningkatnya ketinggian reflectivity inti sel awan $45 \mathrm{dBz}$ diatas freezing level (Holleman, 2001). Selisih H45 dan H0 selanjutnya akan dikonversi menjadi probabilitas hujan es dalam persen (Gambar 1). Ketika selisih ketinggian lebih dari $5.5 \mathrm{~km}$, persentase peluang kejadian hujan es akan lebih dari $100 \%$ (Waldvogel, 1979).

Gambar 1 menunjukan perkembangan metode deteksi hujan es (Hail Detection Algoritm). NEXRAD HDA lama memeriksa karakteristik tertentu, seperti reflectivity badai maksimum dan overhang, dan menerapkan bobot. NEXRAD HDA baru menghitung ketinggian antara freezing level dan tinggi maksimum reflektifitas $45 \mathrm{dBZ}$ dan menerapkan kurva probabilitas yaitu Probability of Hail (POH) (Waldvogel, 1979). Severe Hail Index (SHI) dihitung dengan integrasi vertikal produk energi kinetik hujan es dengan fungsi suhu dan fungsi reflektifitas yang kemudian dikonversi menjadi indeks probabilitas yaitu Probability of Severe Hail (POSH) (Witt, 1998). 


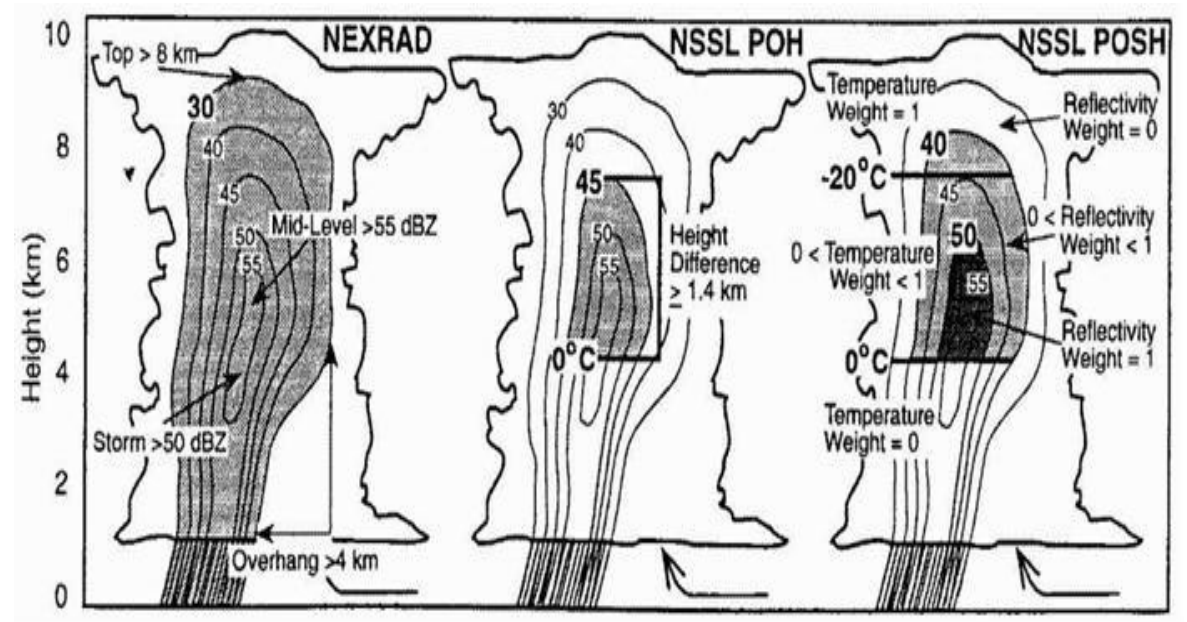

Gambar 1. Skema badai hujan es dan desain setiap Hail Detection Algorithm (Kessinger 1995).

Pengujian metode Waldvogel juga pernah dilakukan di Jakarta dan Bandung, Indonesia oleh Ali dan Sabitul (2016) dengan menggunakan 13 data kasus kejadian hujan es. Hasil penelitian tersebut menunjukkan bahwa nilai POD lebih besar dari nilai FAR, yakni 0.62 untuk nilai POD dan 0.43 untuk nilai FAR sedangkan nilai CSI 0.42. Penelitian tersebut menyatakan bahwa metode Waldvogel memiliki nilai kebenaran yang lebih tinggi dibandingkan tingkat kesalahan. Selanjutnya, Permata (2018) melakukan modifikasi terhadap kriteria parameter metode Waldvogel dengan mengidentifikasi karakteristik kejadian hujan es di wilayah Jawa bagian barat. Dalam penelitian tersebut, didapatkan kriteria parameter Waldvogel modifikasi yaitu dengan Zmaks sebesar $52 \mathrm{dBZ}$, freezing level $5.0 \mathrm{~km}$, dan selisih ketinggian reflectivity dengan freezing level $\left(\mathrm{H}_{\mathrm{Z}}-\mathrm{FL}\right) 1.6$ dengan hasil verifikasi memiliki nilai CSI 0.54 yang lebih tinggi dibandingkan sebelum modifikasi yaitu 0.31. Dalam menentukan kriteria modifikasi, dilakukan analisis secara statistik terhadap 30 data kejadian hujan es dalam radius $0-150 \mathrm{~km}$ terhadap radar cuaca.

Penentuan kriteria metode Waldvogel yang teramati dalam suatu sistem konvektif membutuhkan profil awan vertikal yang utuh. Pengamatan radar cuaca sendiri memiliki limitasi yaitu berupa terbatasnya elevasi scan radar sehinga menghasilkan Blank Zone pada radius yang dekat (Hong dkk., 2015) dan pada jarak objek yang jauh dari radar menyebabkan pengurangan intensitas beam yang berakibat hasil estimasi lebih rendah dari keadaan yang sebenarnya (Holleman, 2006).

Tujuan dari penelitian ini adalah menentukan kriteria parameter Waldvogel baru berdasarkan data kejadian hujan es dengan mempertimbangkan jarak kejadian hujan es terhadap radar cuaca. Penentuan kriteria modifikasi ini didasarkan pada karakteristik parameter Waldvogel dari analisis statistik data klimatologis hujan es yang dikumpulkan. Penelitian ini akan mengelompokkan radius pengamatan kejadian hujan es menjadi tiga, dengan memisahkan jarak pengamatan terdekat dari pusat radar dan jarak yang jauh dari pusat radar. Hasil yang diharapkan berupa kriteria parameter Waldvogel baru yang lebih akurat pada masing-masing kelompok wilayah cakupan radar. Diharapkan modifikasi terhadap kriteria parameter Waldvogel ini dapat menjadi panduan ataupun referensi yang lebih akurat dalam memberikan peringatan dini maupun analisis terhadap kasus kejadian hujan es. 


\section{METODE}

\subsection{Lokasi dan Data Penelitian}

Lokasi penelitian adalah wilayah dalam jangkauan pengamatan radar cuaca Jakarta sejauh $150 \mathrm{~km}$ yang secara administratif mencakup wilayah provinsi DKI Jakarta, Banten, dan Jawa Barat (Gambar 2). Radar cuaca Jakarta terletak pada koordinat $6,1669{ }^{\circ} \mathrm{LS}$ dan $106,6502{ }^{\circ} \mathrm{BT}$. Jangkauan pengamatan radar cuaca Jakarta dikelompokkan menjadi tiga wilayah berdasarkan jarak dari pusat radar yaitu wilayah I berada dalam radius kurang dari $30 \mathrm{~km}$, wilayah II berada di radius 30 hingga $100 \mathrm{~km}$ dan wilayah III berada di radius 100 hingga $150 \mathrm{~km}$. Pengelompokkan tersebut didasarkan pada beberapa limitasi pengamatan radar cuaca dalam mengamati fenomena meteorologi (khususnya awan Cumulunimbus) seperti terdapat Blank Zone pada radius yang dekat (Hong dkk., 2015) dan pengurangan intensitas beam pada jarak objek yang jauh dari radar yang menyebabkan hasil estimasi lebih rendah dari keadaan yang sebenarnya (Holleman, 2006).

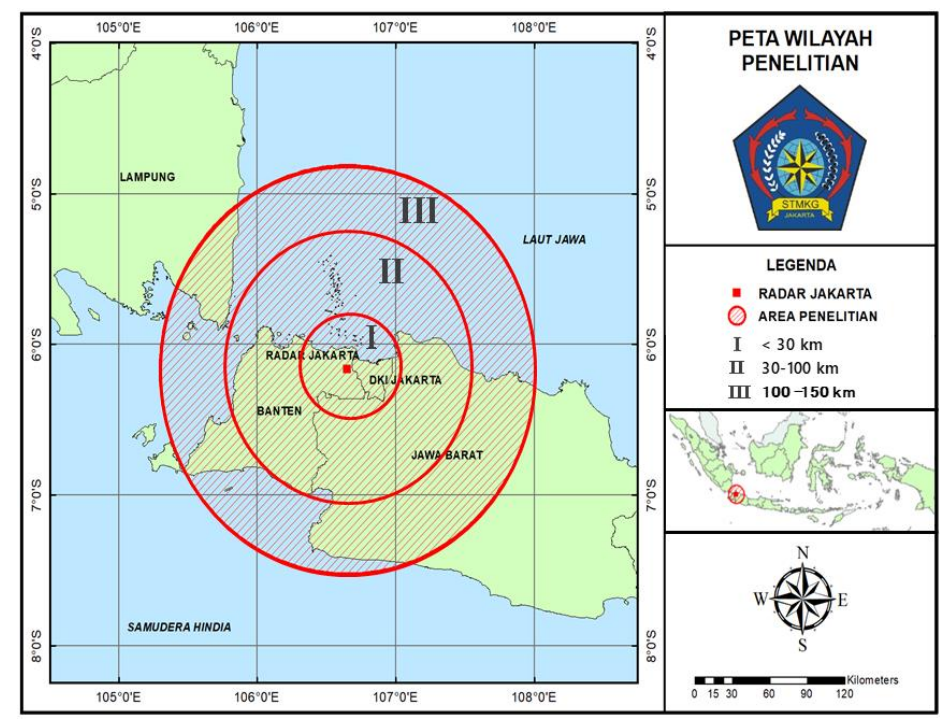

Gambar 2. Peta lokasi penelitian

Data kejadian hujan es yang merupakan laporan dari berita media online yang dikumpulkan dari tahun 2010 hingga 2019 yang masuk pada area lokasi penelitian. Informasi yang dikumpulkan berupa tempat dan tanggal dilaporkan kejadian hujan es. Waktu kejadian yang dilaporkan akan diverifikasi kembali dengan data pengamatan radar cuaca. Kejadian hujan es yang menjadi bahan analisis dalam penelitian ini berjumlah 39 kasus yang dapat dilihat pada Tabel 1

Tabel 1. Tabel Kejadian Hujan Es pada Wilayah I

\begin{tabular}{lccc}
\hline No & Tanggal & Jarak dari Radar Cuaca & Lokasi \\
\hline 1 & 28 Maret 2017 & $15 \mathrm{~km}$ & Jakarta Selatan \\
2 & 22 April 2014 & $14 \mathrm{~km}$ & Palmerah \\
3 & 29 Oktober 2013 & $18 \mathrm{~km}$ & Lebak Bulus \\
4 & 30 Oktober 2011 & $20 \mathrm{~km}$ & Pamulang, Tangsel \\
5 & 27 November 2010 & $20 \mathrm{~km}$ & Klender, Jakarta Timur \\
6 & 21 Oktober 2010 & $23 \mathrm{~km}$ & Cilandak \\
\hline
\end{tabular}


Tabel 2. Tabel Kejadian Hujan Es pada Wilayah II

\begin{tabular}{lccc}
\hline No & Tanggal & Jarak dari Radar Cuaca & Lokasi \\
\hline 1 & 22 Februari 2019 & $86 \mathrm{~km}$ & Kec. Cicantayan, Sukabumi \\
2 & 12 Desember 2018 & $31 \mathrm{~km}$ & Kota Depok \\
3 & 22 November 2018 & $81 \mathrm{~km}$ & Kec. Klari, Karawang \\
4 & 17 November 2018 & $78 \mathrm{~km}$ & Kec. Pacet, Cianjur \\
5 & 12 Juni 2018 & $39 \mathrm{~km}$ & Kec. Jasinga, Bogor Barat \\
6 & 20 Maret 2018 & $31 \mathrm{~km}$ & Depok \\
7 & 22 Oktober 2017 & $35 \mathrm{~km}$ & Bekasi \\
8 & 1 Oktober 2017 & $33 \mathrm{~km}$ & Depok \\
9 & 8 Agustus 2017 & $51 \mathrm{~km}$ & Leuwiliang, Bogor \\
1025 September 2016 & $37 \mathrm{~km}$ & Jatiasih, Bekasi \\
11 & 5 Juli 2016 & $48 \mathrm{~km}$ & Kota Bogor \\
12 & 26 Maret 2016 & $88 \mathrm{~km}$ & Sukabumi \\
1330 November 2015 & $76 \mathrm{~km}$ & Karawang \\
1430 November 2015 & $42 \mathrm{~km}$ & Bogor Barat, Bogor \\
1521 September 2015 & $54 \mathrm{~km}$ & Baranangsiang, Bogor \\
16 & 31 Juli 2015 & $47 \mathrm{~km}$ & Dramaga, Bogor Barat \\
17 & 6 Maret 2014 & $39 \mathrm{~km}$ & Pabuaran, Cibinong \\
18 & 10 Januari 2014 & $44 \mathrm{~km}$ & Cileungsi, Bogor \\
19 & 11 Juni 2012 & $54 \mathrm{~km}$ & Bogor Selatan \\
\hline
\end{tabular}

Tabel 3. Tabel Kejadian Hujan Es pada Wilayah III

\begin{tabular}{cccc}
\hline No & Tanggal & Jarak dari Radar Cuaca & Lokasi \\
\hline 1 & 23 Februari 2019 & $134 \mathrm{~km}$ & Cigadung, Kota Bandung \\
2 & 12 Februari 2019 & $138 \mathrm{~km}$ & Kiaracodong, Kota Bandung \\
3 & 10 Januari 2019 & $134 \mathrm{~km}$ & Kota Bandung \\
4 & 22 Juli 2018 & $141 \mathrm{~km}$ & Bojongsoang, Bandung \\
5 & 20 Maret 2018 & $134 \mathrm{~km}$ & Bandung \\
6 & 3 Mei 2017 & $135 \mathrm{~km}$ & Jl. Braga, Bandung \\
7 & 17 Maret 2017 & $137 \mathrm{~km}$ & Bandung \\
8 & 7 Oktober 2015 & $137 \mathrm{~km}$ & Bandung \\
9 & 24 Desember 2014 & $137 \mathrm{~km}$ & Bandung \\
10 & 10 Januari 2014 & $135 \mathrm{~km}$ & Bandung \\
11 & 8 Oktober 2013 & $136 \mathrm{~km}$ & Bandung \\
1210 September 2012 & $133 \mathrm{~km}$ & Bandung \\
132 29 November 2010 & $144 \mathrm{~km}$ & Bandung \\
14 & 24 April 2010 & $137 \mathrm{~km}$ & Bandung \\
\hline
\end{tabular}

Data radar cuaca yang digunakan adalah raw data radar cuaca Jakarta dengan format volume (.vol) yang didapatkan dari BMKG sub-bidang pengolahan citra radar. Metode operasional radar cuaca Jakarta menggunakan teknik Volume Coverage Pattern (VCP) 21 yang memiliki 11 elevasi, yaitu dari $0.50^{\circ}$ hingga $19.50^{\circ}$. Radar cuaca Jakarta merupakan radar cuaca Doppler dengan tipe C-Band, merek EEC serta menggunakan polarisasi tunggal (single polarization). Kemudian data satelit Himawari 7 dan 8 yang digunakan adalah data kanal IR-1 (infrared) atau B13 yang diolah untuk mendapatkan data ketinggian freezing level. 
Format data yang digunakan yaitu.$Z$ dengan resolusi data $5.55 \mathrm{~km} \mathrm{x} 5.55 \mathrm{~km}$ yang didapatkan dari BMKG sub-bidang pengolahan citra satelit. Data satelit Himawari 7 untuk data tahun 2010-2015 dan data satelit Himawari 8 untuk data tahun 2016-2019.

\section{Metode Penelitian}

Metode yang digunakan dalam penelitian ini adalah metode deskriptif dengan melakukan pengolahan data, menganalisis dan menginterpretasikan citra radar cuaca maupun satelit pada setiap kasus - kasus kejadian hujan es. Selanjutnya, hasil berupa data kuantitatif diolah secara statistik untuk menentukan kriteria parameter Waldvogel modifikasi. Kemudian teknik/metode eksperimental dilakukan untuk mengujikan setiap kriteria yang telah didapatkan dan dilakukan verifikasi untuk dapat mengetahui efektifitas atau performa dari suatu kriteria.

Penelitian dimulai dengan mengumpulkan kejadian hujan es melalui laporan media berita online. Kejadian hujan es dikelompokkan menjadi tiga berdasarkan wilayah cakupan radar cuaca, yaitu wilayah I (kurang dari $30 \mathrm{~km})$, wilayah II $(30-100 \mathrm{~km})$ dan wilayah III (100-150 $\mathrm{km})$. Selanjutnya, menentukan nilai parameter kriteria Waldvogel dengan menggunakan produk radar Maximum Display (MAX) dan Echo Height (EHT) serta data satelit kanal IR-1 (infrared) atau kanal B13 yang diolah dengan aplikasi SATAID (Satellite Animation and Interactive Diagnosis). Kasus kejadian hujan es pada wilayah II digunakan untuk acuan penentuan kriteria modifikasi dengan anggapan bahwa pada radius 30 hingga $100 \mathrm{~km}$ limitasi pengamatan radar adalah yang paling minimum. Setelah itu, dilakukan penentuan kriteria parameter waldvogel modifikasi melalui analisis statistik parameter waldvogel yang didapatkan. Nilai reflectivity maksimum dimasukan ke dalam tabel distribusi frekuensi data kelompok untuk mendapatkan nilai reflectivity maksimum rata-rata (mean), median, dan modus. Selanjutnya ketinggian ketiga nilai reflectivity maksimum tersebut dihitung selisihnya dengan ketingian freezing level. Maka didapatkan tiga keriteria Waldvogel modifikasi yaitu : kriteria Waldvogel 1 dari reflectivity rata-rata (mean), kriteria Waldvogel 2 dari reflectivity median, dan kriteria Waldvogel 3 dari reflectivity modus.

Berikutnya dilakukan perhitungan Probability of Hail $(\mathrm{POH})$ seluruh kejadian hujan es dengan menggunakan tiga kriteria parameter Waldvogel modifikasi. Perhitungan $\mathrm{POH}$ dilakukan dengan menggunakan produk radar Reflectivity-based Hail Warning (ZHAIL). Perhitungan probabilitas kejadian hujan es dalam metode Waldvogel dirumuskan :

dimana :

$$
P O H=\frac{100 \%}{\Delta H\left(H_{T H}^{\prime}-\left(H_{0}+H_{\text {Hail }}\right)+\frac{\Delta H}{2}\right.}
$$

$P O H=$ Probability of Hail

$\Delta \quad=$ Interval transition

$H_{0} \quad$ = Tinggi freezing level

$H_{\text {Hail }} \quad=$ Ketebalan antara reflectivity dengan tinggi freezing level

Hasil yang diperoleh pada masing-masing wilayah kemudian diverifikasi menggunakan tabel kontingensi 2x2 (Tabel 4) untuk mendapatkan nilai dari Possibility of Detection (POD), False Alarm Ratio (FAR) dan Critical Succes Index (CSI) berdasarkan empat kategori (Wilks, 1995). 
Tabel 4. Tabel kontingensi $2 \times 2$ kejadian hujan es

\begin{tabular}{ccc}
\hline \multirow{2}{*}{ Prakiraan } & \multicolumn{2}{c}{ Observasi } \\
\cline { 2 - 3 } & Hail & No Hail \\
\hline Hail & Hits & False Alarm \\
No Hail & Miss & Norrect \\
\end{tabular}

Dengan menggunakan rumus sebagai berikut :

$$
\begin{gathered}
P O D=\frac{\text { Hits }}{(\text { Hits }+ \text { Miss })} \\
\text { FAR }=\frac{\text { False Alarm }}{(\text { Hits }+ \text { False Alarm })} \\
C S I=\frac{\text { Hits }}{(\text { Hits }+ \text { Miss }+ \text { False Alarm })}=\left[\frac{1}{P O D}+\frac{1}{1-F A R}-1\right]^{-1}
\end{gathered}
$$

Nilai POD yang tinggi dan FAR rendah menunjukkan bahwa metode tersebut dianggap baik. Sedangkan nilai CSI untuk melihat performa metode yang digunakan, dimana hasil dengan nilai CSI tertinggi menunjukkan bahwa metode tersebut dianggap baik (Holleman, 2001). Langkah terakhir yaitu mengambil kesimpulan kriteria Waldvogel dengan tingkat akurasi terbaik pada masing-masing wilayah. Metode eksperimental dilakukan dengan menguji efektivitas kriteria Waldvogel modifikasi sehingga akan didapatkan kriteria terbaik sesuai pengelompokkan masing-masing wilayah cakupan radar cuaca.

Langkah-langkah pengolahan data dan verifikasi tersebut di atas direpresentasikan dalam diagram alir berikut ini (Gambar 3).

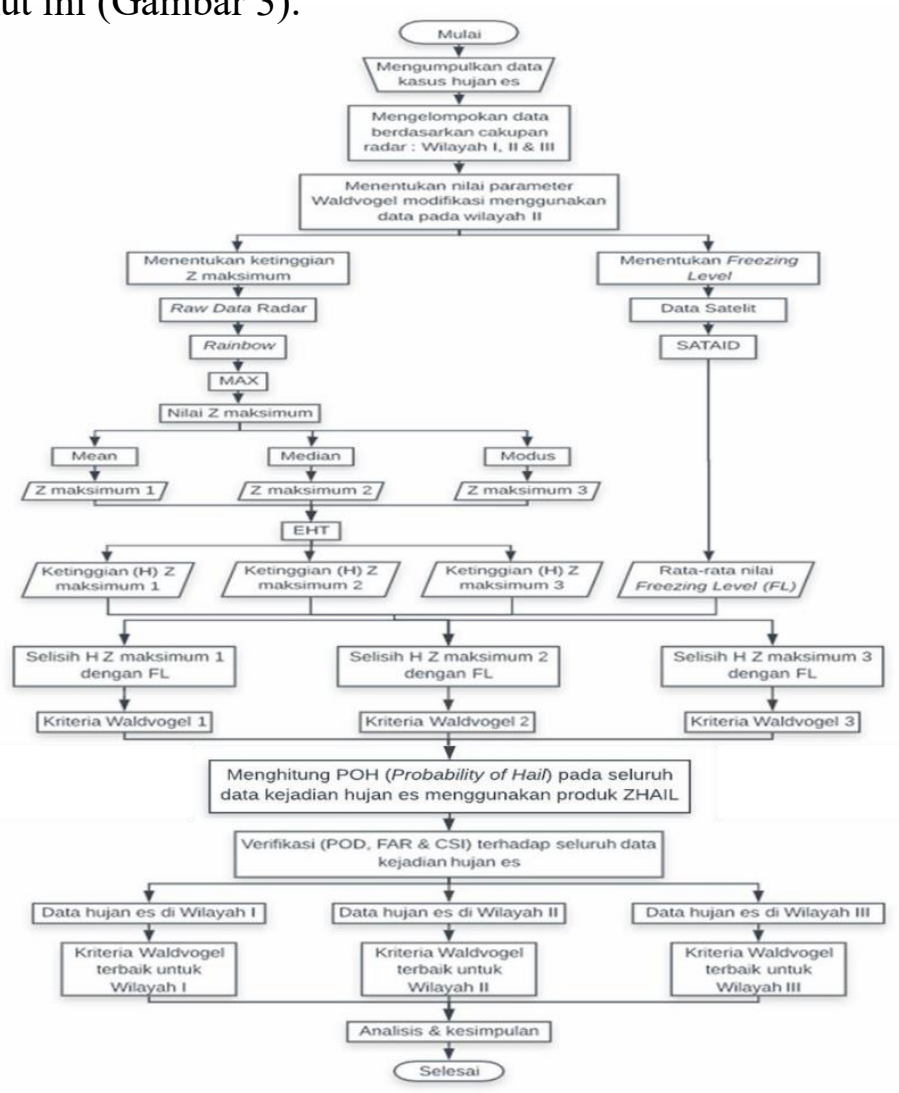

Gambar 3. Diagram Alir Penelitian 


\section{HASIL DAN PEMBAHASAN}

\subsection{Analisis Karakteristik Nilai Parameter Waldvogel Modifikasi}

Analisis karakteristik dilakukan terhadap nilai reflectivity maksimum (Zmaks), ketinggian reflectivity maksimum dan freezing level pada setiap kejadian hujan es dalam cakupan radar dalam wilayah II sebanyak 19 kasus kejadian. Analisis karakteristik parameter tersebut mengambil kasus kejadian hujan es pada wilayah II dimaksudkan untuk mendapatkan kriteria parameter dengan efek pengaruh limitasi radar yang paling minimum jika dibandingkan dengan wilayah I dan III.

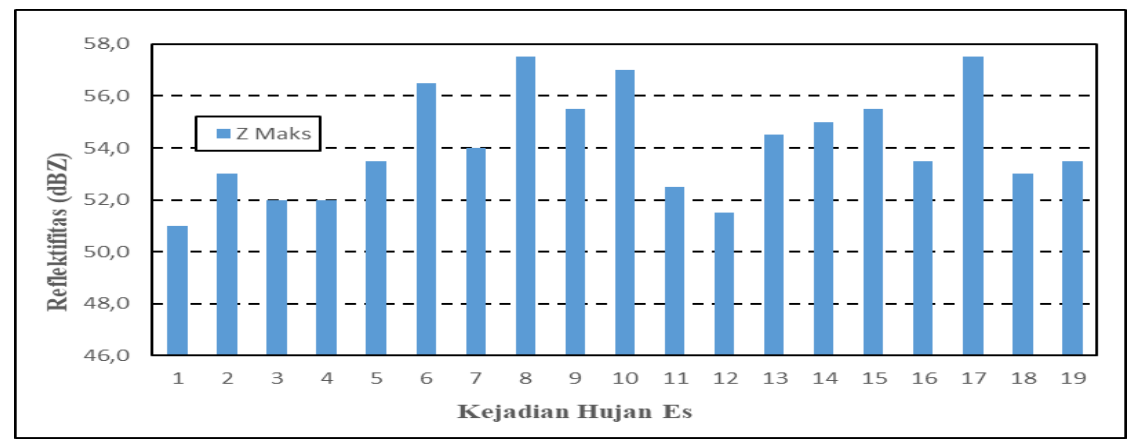

Gambar 4. Grafik Nilai Z Maksimum

Hasil pengolahan menunjukan nilai reflectivity maksimum terendah adalah $51 \mathrm{dBZ}$ dan nilai reflectivity maksimum tertinggi adalah $57 \mathrm{dBz}$ (Gambar 4). Hal ini menunjukkan bahwa seluruh kasus hujan es yang diteliti disebabkan oleh adanya pertumbuhan awan konvektif jenis Cumulonimbus yaitu yang memiliki nilai reflectivity lebih dari $40 \mathrm{dBZ}$ (Roberts dan Rutledge, 2003). Dari hasil tersebut, dilakukan analisis statistik untuk menentukan nilai ratarata, median, dan modus dari nilai Zmaks pada 19 kasus tersebut. Sebelumnya, 19 nilai reflectivity dibagi ke dalam enam rentang kelas berdasarkan jangkauan data untuk ditampilkan dalam bentuk tabel distribusi frekuensi (Tabel 5). Setelah dilakukan penghitungan statistik didapatkan nilai median sebesar $53.60 \mathrm{dBZ}$, nilai modus $53.91 \mathrm{dBZ}$, serta nilai rata-rata 54.81 dBZ. Untuk menentukan kriteria, hasil akhir perhitungan dibulatkan untuk menyederhanakan.

Tabel 5. Distribusi frekuensi nilai Zmaks (dBZ) dan analisis statistik

\begin{tabular}{|c|c|}
\hline Zmaks & Frekuensi \\
\hline $51.0-52.3$ & 4 \\
\hline $52.4-53.7$ & 6 \\
\hline $53.8-55.1$ & 3 \\
\hline $55.2-56.5$ & 3 \\
\hline $56.6-57.9$ & 3 \\
\hline Minimum & 51 \\
\hline Maksimum & 57 \\
\hline Rata-rata & 55 \\
\hline Median & 53 \\
\hline Modus & 54 \\
\hline
\end{tabular}

Dari nilai tersebut dilakukan pengolahan ketinggian reflectivity dengan menggunakan produk EHT pada aplikasi Rainbow 5.49.11. Pengaturan produk EHT diubah pada bagian 
Minimum Reflectivity dengan nilai 53, 54, dan $55 \mathrm{dBZ}$ sesuai dengan nilai yang didapatkan pada langkah sebelumnya. Kemudian didapatkan nilai ketinggian dalam kilometer $(\mathrm{km})$ yang selanjutnya menjadi nilai ketinggian reflectivity maksimum (Hz) yang kemudian akan diambil rata-ratanya. Parameter terebut menjadi salah satu parameter dalam metode waldvogel.

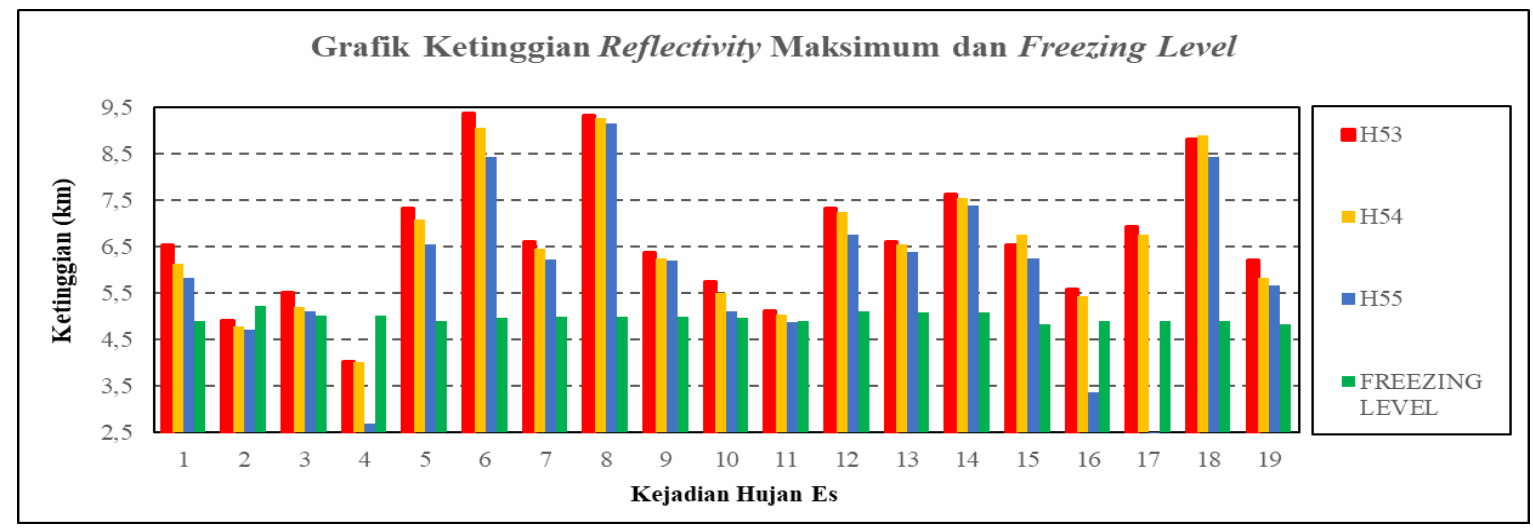

Gambar 5. Grafik Ketinggian Reflectifity Maksimum dan Freezing Level

Selain itu parameter metode Waldvogel selanjutnya adalah freezing level. Profil nilai ketinggian reflectivity maksimum dan freezing level pada 19 kasus kejadian hujan es dapat dilihat pada Gambar 5. Secara umum terlihat nilai minimum untuk H53, H54, dan H55 berturut-turut adalah $3.84,3.84$, dan $3.72 \mathrm{~km}$. Nilai maksimumnya berturut-turut adalah 9.33, 9.27 , dan $9.15 \mathrm{~km}$. Nilai rata-rata, yaitu $6.65,6.51$, dan $6.37 \mathrm{~km}$. Sementara itu nilai freezing level berkisar antara 4.8 hingga $5.1 \mathrm{~km}$ dengan rata-rata $4.9 \mathrm{~km}$. Nilai yang digunakan sebagai modifikasi adalah nilai rata-rata dari masing-masing parameter modifikasi.

\subsection{Kriteria Waldvogel Modifikasi}

Berdasarkan analisis statistik maka diambil empat nilai Zmaks sebagai kriteria modifikasi yaitu 53, 54, dan $55 \mathrm{dBZ}$. Nilai ini jauh lebih tinggi dari nilai awal kriteria Waldvogel yaitu $45 \mathrm{dBZ}$. Begitupun dengan ketinggian FL, didapatkan nilai yang lebih tinggi dari kriteria awal sebesar $3.0 \mathrm{~km}$. Sedangkan untuk selisih antara ketinggian reflectivity maksimum dengan freezing level (HZ-FL) hasilnya relatif sama dengan kriteria awal yaitu sebesar 1.2 hingga $1.6 \mathrm{~km}$.

Tabel 6. Kriteria parameter-parameter metode Waldvogel modikfikasi

\begin{tabular}{lcccc}
\hline & $\mathbf{Z ~ ( d B Z )}$ & $\mathbf{H}_{\mathbf{Z}}$ & FL & $\mathbf{H}_{\mathbf{Z}}-\mathbf{F L}$ \\
\hline Waldvogel 1 & 5 & 1 & 9 & .2 \\
Waldvogel 2 & 4 & 5 & 9 & .6 \\
Waldvogel 3 & 3 & 6 & 9 & .3 \\
\hline
\end{tabular}

Dengan didapatkannya 3 nilai reflectivity maksimum dan nilai rata-rata freezing level maka dihasilkan 3 kriteria modifikasi metode Waldvogel yaitu Waldvogel 1, Waldvogel 2 \& Waldvogel 3 (Tabel 6). Ketiga kriteria inilah yang digunakan untuk menghitung Probability of Hail (POH). Hasil perhitungan ini kemudian diverifikasi menggunakan produk ZHAIL pada aplikasi rainbow dan dilakukan perbandingan dengan hasil verifikasi jika menggunakan keriteria awal yaitu tanpa modifikasi. 


\subsection{Verifikasi}

Verifikasi dilakukan terhadap nilai probabilitas hujan es (Probability of Hail) yang teramati di radar pada seluruh kasus kejadian hujan es. Verifikasi terhadap kasus kejadian hujan es dilakukan secara terpisah menurut pembagian wilayah yaitu Wilayah I, Wilayah II dan Wilayah III. Produk radar ZHAIL dengan parameter modifikasi menghasilkan nilai POH yang bervariasi bergantung pada kritreria yang ditentukan (Waldvogel 1, Waldvogel 2 \& Waldvogel 3). Selain itu hasil verifikasi pada masing-masing wilayah menunjukan perbedaan yang cukup signifikan antara satu dengan yang lain.

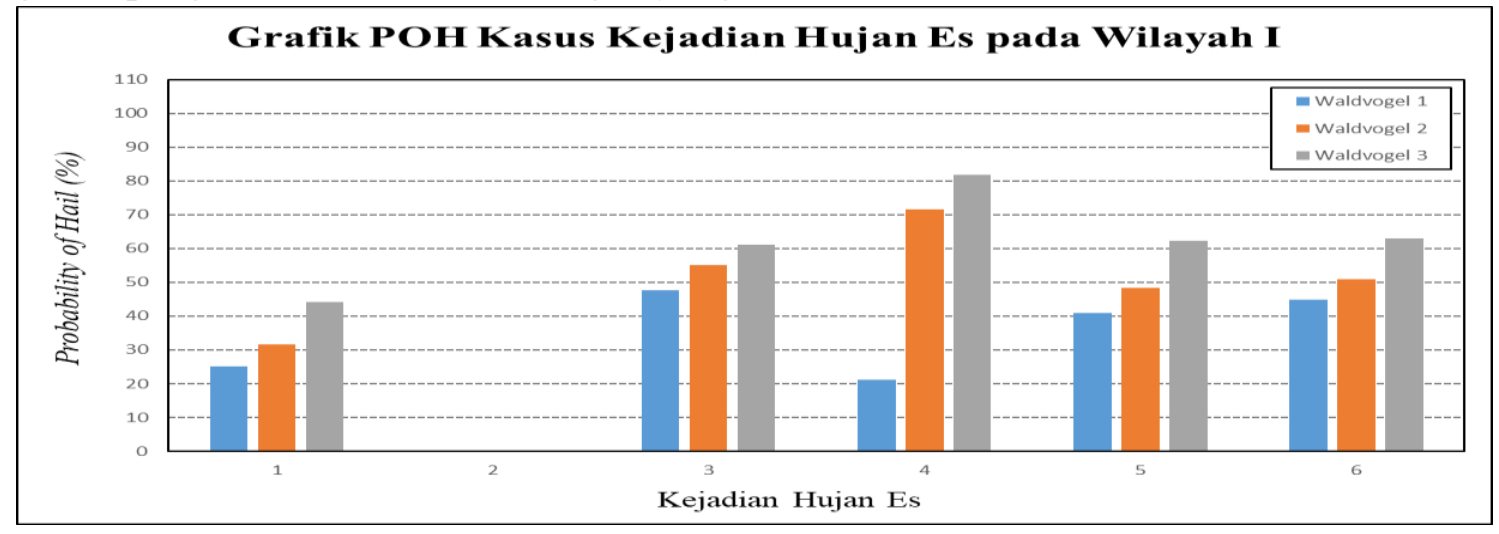

Gambar 6. Grafik POH kasus kejadian hujan es Wilayah I

Dari Gambar 6 terlihat nilai POH kejadian hujan es di wilayah I berkisar 20-30\% untuk kriteria Waldvogel I, 30-72\% untuk Waldvogel 2 dan 44-82 \% untuk Waldvogel 3. Nilai POH pada kasus kejadian 22 April 2014 di Palmerah menunjukan hasil 0\% untuk semua kriteria modifikasi. Hal tersebut dikarenakan jarak yang cukup dekat antara kasus kejadian dengan pusat radar yaitu $14 \mathrm{~km}$. Hal ini membuat profil awan penyebab hujan es tidak tertangkap seluruhnya oleh radar cuaca akibat terbatasnya elevasi pengamatan atau sering disebut dengan cone of silence. Kondisi tersebut menyebabkan nilai ketinggian reflectivity maksimum yang teramati bernilai dibawah freezing level dan kemudian menghasilkan nilai nilai $\mathrm{POH} 0 \%$

Tabel 7. Nilai POD, FAR dan CSI dari POH Wilayah I

\begin{tabular}{cccc}
\hline & POD & FAR & CSI \\
\hline Waldvogel 1 & 0.83 & 0.61 & 0.35 \\
Waldvogel 2 & 0.83 & 0.61 & 0.35 \\
Waldvogel 3 & 0.83 & 0.61 & 0.35 \\
Waldvogel Awal & 1.00 & 0.87 & 0.18
\end{tabular}

Verifikasi menunjukan nilai yang sama dari tiga kriteria yang diujikan (Tabel 7). Hal ini disebabkan oleh perbedaan nilai POH antara ketiga kriteria yang cenderung tidak menunjukan perbedaan yang signifikan jika dibandingkan dengan hasil perhitungan $\mathrm{POH}$ di wilayah II. Hal tersebut dimungkinkan karena kontur reflectivity pada awan bagian atas diatas freezing level relatif menunjukan nilai yang sama. Hal ini disebabkan awan bagian atas/puncak mencapai elevasi tertinggi dari pengamatan beam radar sehingga sangat memungkinkan ada bagian awan yang tidak teramati oleh beam radar dan nilai yang masih teramati akan memiliki nilai ketinggian yang berdekatan atau bahkan sama. Jika dibandingkan dengan metode Waldvogel dengan kriteria awal, nilai POD dan FAR Waldvogel awal lebih tinggi yaitu 
masing-masing 1.0 dan 0.87. Tetapi, nilai CSI dengan modifikasi menunjukan nilai yang lebih baik dari kriteria awal yang hanya menunjukan nilai CSI 0.18. Hal tersebut dikarenakan metode dengan kriteria awal menunjukan hasil deteksi yang overestimate. Dalam penelitian Permata (2018) juga menyimpulkan hasil yang overestimate jika menggunakan metode awal tanpa modifikasi. Metode tersebut cenderung sering mendeteksi terjadi hujan es pada wilayah II yang faktanya tidak terjadi hujan es.

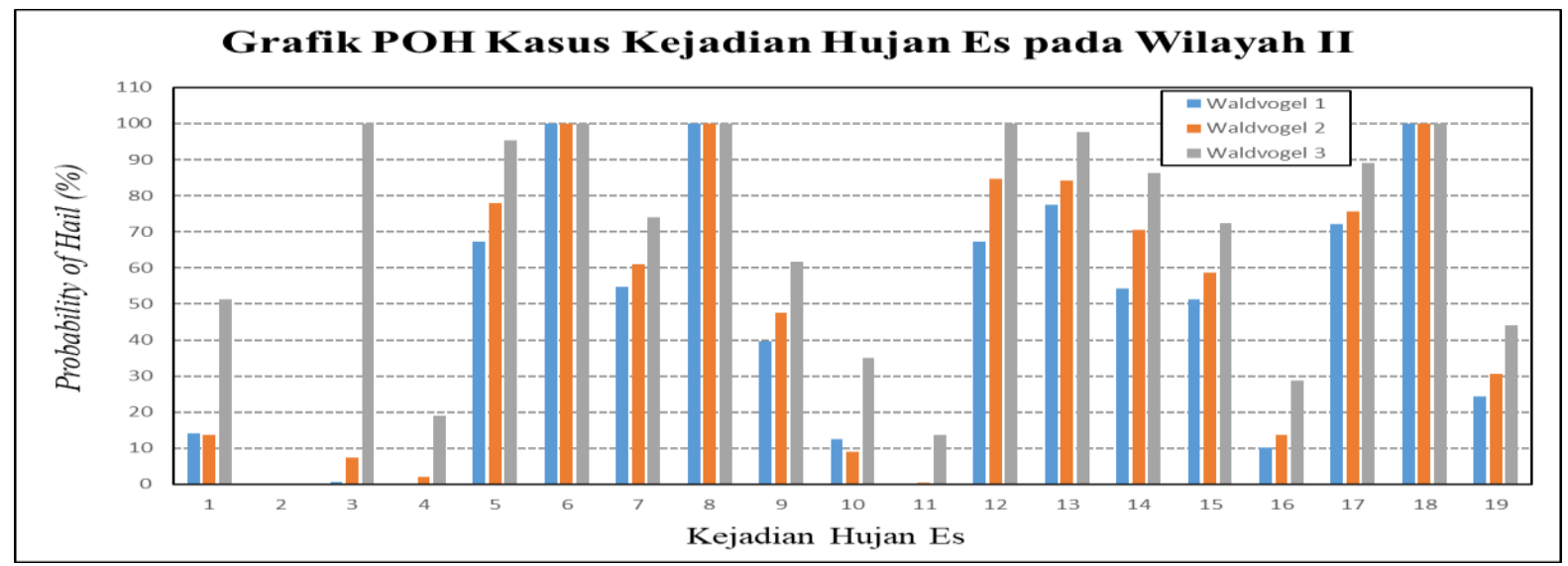

Gambar 7. Grafik POH kasus kejadian hujan es Wilayah II

Perhitungan POH tiga kriteria metode Waldvogel modifikasi yang diujikan pada Gambar 7 menunjukkan variasi $\mathrm{POH}$ yang bervariasi. Sebagian besar kejadian hujan es menunjukkan Probability of Hail $(\mathrm{POH})$ di atas $60 \%$. Hal ini disebabkan reflektivity profil awan vertikal dapat teramati secara utuh oleh radar. Limitasi radar seperti blank zone maupun pengurangan intensitas beam pada wilayah II adalah paling minimum.

Tabel 8. Nilai POD, FAR dan CSI dari POH Wilayah II

\begin{tabular}{cccc}
\hline & POD & FAR & CSI \\
\hline Waldvogel 1 & 0.84 & 0.33 & 0.59 \\
Waldvogel 2 & 0.89 & 0.32 & 0.62 \\
Waldvogel 3 & 0.94 & 0.31 & 0.66 \\
Waldvogel Awal & 1.00 & 0.80 & 0.13 \\
\hline
\end{tabular}

Hasil verifikasi pada nilai POH Wilayah II (Tabel 8) menunjukkan bahwa Waldvogel 3 dengan nilai POD, FAR dan CSI berturut-turut $0.94,0.31$ dan 0.66 adalah metode yang paling tepat diterapkan. Selain karena memiliki nilai POD yang tinggi, nilai FAR yang terendah dan CSI yang tertinggi memuat Waldvogel 3 menjadi kriteria yang paling baik. 


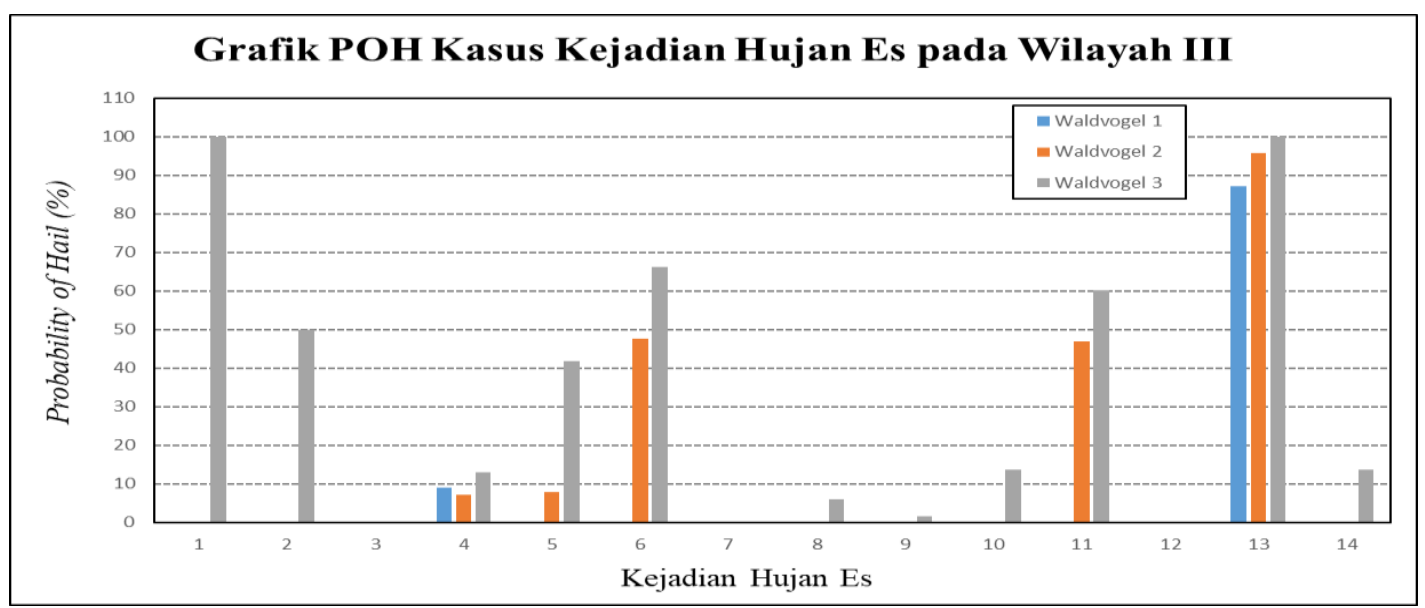

Gambar 8. Grafik POH kasus kejadian hujan es Wilayah III

Dari Gambar 8 terlihat nilai POH kejadian hujan es di wilayah III cukup berbeda dengan $\mathrm{POH}$ di wilayah I dan II. Hasil POH banyak kasus kejadian yang memiliki nilai POH $0 \%$. Kriteria Waldvogel 3 bernilai $9 \%$ dan $86 \%$ untuk kasus kejadian masing-masing 22 Juli 2018 dan 8 Oktober 2013. Kriteria Waldvogel 2 berkisar 7-96 \% pada kasus kejadian 22 Juli 2018, 20 Maret 2018, 3 Mei 2017, 8 Oktober 2013 dan 29 November 2010. Kriteria Waldvogel 3 memiliki nilai presentasi yang lebih tinggi berkisar 3-100\% dengan jumlah kasus kejadian dengan tidak terdeteksi $(0 \%)$ berjumlah 3 kasus. Rendahnya nilai POH pada masing-masing kriteria dimungkinkan akibat kasus-kasus kejadian pda wilayah ini memiliki jarak yang jauh dari pusat radar. Selain terkena efek beam spreading (pengurangan intensitas energi beam) (Holleman, 2006), lokasi terbentuknya awan yang terletak jauh dari radar memungkinkan beam radar yang hanya mendeteksi sebagian struktur awan bagian atas. Hal ini menyebabkan nilai ketinggian reflectivity rendah pada radar yang jika lebih rendah dari ketinggian freezing level makan nilai $\mathrm{POH}$ akan bernilai $0 \%$.

Tabel 9. Nilai POD, FAR dan CSI dari POH Wilayah III

\begin{tabular}{lccc}
\hline & POD & FAR & CSI \\
\hline Waldvogel 1 & 0.14 & 0.80 & 0.09 \\
Waldvogel 2 & 0.35 & 0.61 & 0.22 \\
Waldvogel 3 & 0.78 & 0.41 & 0.50 \\
Waldvogel Awal & 0.87 & 0.70 & 0.60 \\
\hline
\end{tabular}

Verifikasi menunjukan kriteria Waldvogel 3 lebih baik dari 2 kriteria lainnya dengan nilai POD, FAR dan CSI berturut-turut 0.78, 0.41 dan 0.50. Akan tetapi hasil ini masih lebih rendah dibandingkan dengan kriteria metode awal dengan nilai POD, FAR dan CSI berturutturut $0.87,0.70$ dan 0.60 . Hal ini berarti untuk wilayah 3 kriteria yang paling baik diterapkan adalah kriteria metode Waldvogel awal dengan nilai Zmaks yang rendah yaitu 45. Hal ini sesuai dengan sifat radar mengalami pengurangan intensitas energi beam yang dipancarkan. Sehingga nilai reflectivity yang besar pada jarak yang dekat akan terdeteksi memiliki nilai reflectivity yang lebih rendah di jarak yang lebih jauh. Maka kriteria dengan treshold nilai reflectivity yang lebih rendah menjadi pilihan yang tepat. 


\section{KESIMPULAN DAN SARAN}

Berdasarkan hasil penelitian dapat disimpulkan deteksi hujan es di tiga wilayah menghasilkan rata-rata nilai probabilitas yang berbeda-beda yang merupakan akibat dari perbedaan jarak dari radar cuaca. Hasil verifikasi menunjukan metode Waldvogel modiifikasi menghasilkan performa yang lebih baik dibandingkan metode Waldvogel awal untuk wilayah I dan II dengan kriteria metode Waldvogel modifikasi yang paling baik yaitu Waldvogel 3 . Sedangkan untuk wilayah III, nilai kriteria yang lebih baik adalah Waldvogel tanpa modifikasi.

Penambahan kasus kejadian dan lokasi cakupan yang lebih luas perlu dilakukan untuk memperoleh hasil yang lebih akurat. Selain itu pengaplikasian hasil penelitian dalam oprasional secara langsung juga sangat berguna untuk mengetahui sebarapa akurat hasil yang didapatkan.

\section{DAFTAR PUSTAKA}

Hidayati, S. dan Ali, A., 2016, Uji Metode Waldvogel sebagai Indikator Probabilitas Hujan Es di Indonesia Berbasis Data Radar Cuaca Doppler, Prosiding Seminar Hari Meteorologi Dunia 2016, STMKG, Jakarta.

Holleman, I., 2001, Hail detection using single-polarization radar, Scientific Report KNMI WR-2001- 01, Belanda.

Holleman, I., 2006, Bias adjustment of radar-based 3-hour precipitation accumulations, Technical Report KNMI TR-290, Belanda.

Hong, Y., Gourley, J. J., 2015, Radar Hydrology: Principes, Models, and Applications, CRC Press, New York.

Kessinger, C. J., E. A. Brandes, and J. W. Smith: 1995, A comparison of the NEXRAD and NSSL hail detection algorithms. 27th conference on Radar Meteorology, AMS, 603605.

Lutgens, F. K. dan Tarbuck, E. J., 2013, The Atmosphere: an Introduction to Meteorology, 12th ed.Pearson Education Inc., New York.

Permata, C.A.D., 2018, Modifikasi Metode Waldvogel Berdasarkan Identifikasi Karakteristik Hujan Es di Wilayah Jawa Bagian Barat, Skripsi, Program Sarjana Terapan Meteorologi, Sekolah Tinggi Meteorologi Klimatologi dan Geofisika, Tangerang.

Roberts, R. D. dan S. Rugledge, 2003, Nowcasting storm initiation and growth using GOES-8 and WSR-88D data, Weather and Forecasting, 18, 562-584.

Rogers, R.R., Yau, M.K, 2006, A Short Course in Cloud Physiscs (Third Edition): Hal 235. Burlington: Elsevier Science.

Skripniková, K. dan Řezáčová, D., 2014, Radar-based hail detection, Atmospheric Research, $144,175-185$.

Waldvogel, A., Federer, B., dan P. Grimm, 1979, Criteria for the detection of hail cells, J. Appl. Meteor., 18, 1521-1525.

Wilks, D.S, 1995, Statistical methods in the atmospheric sciences. Academic Press. Chapter 7.

Witt, A., Eilts, M. D., Stumpf, G. J., Johnson, J. T., Mitchell, E. D. W., dan Thomas, K. W., 1998, An Enhanced Hail Detection Algorithm for the WSR-88D. Weather and Forecasting, 13(2), 286-303.

Zakir, A., 2008, Modul Praktis Analisis dan Prakiraan Cuaca, BMKG, Jakarta. 